\title{
Mortgage Market Development, Savings, and Growth
}

Xiaowei Li 


\title{
IMF Working Paper
}

Middle Eastern Department

\section{Mortgage Market Development, Savings, and Growth}

\author{
Prepared by Xiaowei $\mathrm{Li}^{1}$
}

Authorized for distribution by Pierre Dhonte

March 2001

\begin{abstract}
The views expressed in this Working Paper are those of the author(s) and do not necessarily represent those of the IMF or IMF policy. Working Papers describe research in progress by the author(s) and are published to elicit comments and to further debate.
\end{abstract}

Jappelli and Pagano (1994) argues that tightening the borrowing constraints in the mortgage markets promotes savings. Employing a six-period overlapping generations model with endogenous growth and a method of simulation calibrated on the Middle East, this paper demonstrates that the above argument is tenable only if consumers do not alter their tenure choices. Consumers do, however, postpone or forsake the purchase of a house under severely restrictive borrowing constraints, causing the savings and growth rates to fall. Therefore, for countries with scarce mortgage availability like those in the Middle East, expanding the mortgage markets to some extent is conducive to savings and growth.

JEL Classification Numbers:E21

Keywords: Middle East, Mortgage, Savings, Growth

Author's E-Mail Address: $\underline{\text { li@stanford.edu }}$

\footnotetext{
${ }^{1}$ I am grateful to Pierre Dhonte for his support and comments. I also owe tremendous thanks to Fumio Hayashi who kindly offered me the FORTRAN codes that he wrote for Hayashi et al (1988). In addition, I greatly thank Ronald McKinnon, Shujing Li, Beatrix Paal, Bertrand Renaud, and Robert Buckley for their helpful comments and my colleagues at the IMF and the World Bank for their information on the mortgage markets in the Middle East.
} 


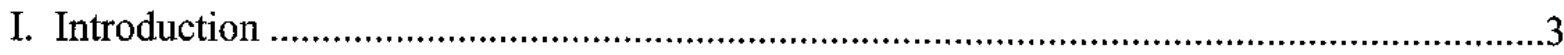

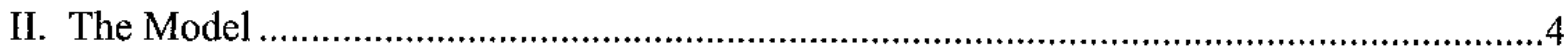

III. Parameterization of the Model .................................................................................

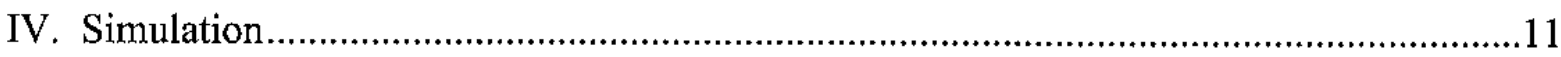

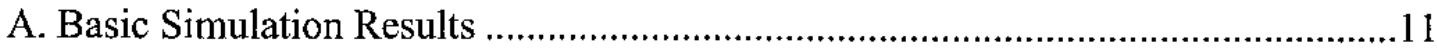

B. Savings, Growth, and Liquidity Constraints ....................................................12

C. Welfare and Liquidity Constraints ................................................................. 16

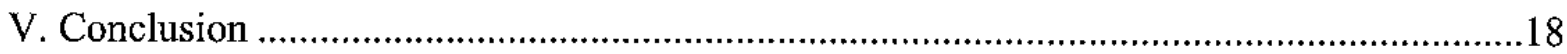

Figures

1. Savings and Liquidity Constraints, Case I ............................................................... 14

2. Growth and Liquidity Constraints, Case I .........................................................14

3. Savings and Liquidity Constraints, Case III ........................................................ 15

4. Growth and Liquidity Constraints, Case III ...........................................................15

5. Consumption and Liquidity Constraints ............................................................17

6. Welfare and Liquidity Constraints..................................................................17

\section{Text Tables}

1. The Effects of Downpayment Ratios on Savings and Growth: Case I......................19

2. The Effects of Downpayment Ratios on Savings and Growth: Case II......................20

3. The Effects of Downpayment Ratios on Savings and Growth: Case III ...................21

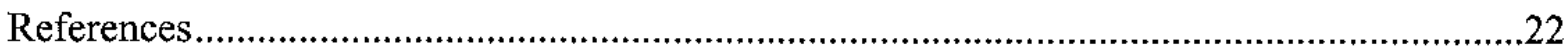




\section{INTRODUCTION}

There are two channels by which the development of financial markets affects the increase in output: (a) the reallocation of capital and the improvement in marginal productivity of capital; and (b) the accumulation of capital or the increment in savings. Regarding the first channel, most studies agree that financial markets facilitate more efficient allocation of investment. In the latter, although there is little doubt that augmented savings lead to increased output, there is considerable debate on the effects of financial market development on savings. McKinnon (1973) and Shaw (1973) argue that the elimination of financial repression narrows the wedge between borrowing and lending interest rates and therefore promotes savings. However, from the perspective of risk-sharing, Aiyagari (1994) and Devereux and Smith (1994) demonstrate that the development of financial intermediaries unambiguously reduces precautionary savings. In particular, Jappelli and Pagano (1994) applies a three-period overlapping generations model to prove that binding liquidity constraints on consumer credit can increase the aggregate savings rates, and that among the mainly OECD countries, less-developed mortgage markets are associated with higher savings rates.

This paper uses a six-period overlapping generations model with endogenous growth and a simulation method to reexamine the effects of mortgage credit availability on savings and output growth. The simulation is calibrated on the Middle East due to the facts that mortgage markets are negligible and that housing demand caused by fast population growth is high. The simulation results indicate that for a given tenure choice of housing, the more restrictive the liquidity constraints in the mortgage markets, the higher the savings rates are-an observation that is consistent with Jappelli and Pagano (1994). However, the results also show that when the liquidity constraints are too stringent, a utility-maximizing household will choose to relax its constraints by delaying or even foregoing the purchase of a house. When either case occurs, unfortunately, the savings rates decline and stay at a relatively lower level. To put it differently, the liquidity constraints in the mortgage markets raise longrun savings and growth to an extent that depends on the severity of the constraints, and liquidity constraints that are too strict hinder savings and growth. On the basis of such findings, the policy recommendation of this paper is contrary to that of Jappelli and Pagano (1994). Instead of proposing tightening mortgage credit, this paper suggests that for countries like those in the Middle East where mortgage markets are minimal, expansion of the mortgage markets leads to higher savings and growth rates and therefore should be encouraged.

In order to keep the focus, this paper will ignore the interesting topics of why the mortgage markets are small and what the possible strategies are to develop the mortgage markets. ${ }^{2}$ The

\footnotetext{
${ }^{2}$ For a discussion on the reasons why relatively little mortgage credit is supplied by formal financial intermediaries in developing countries, see Buckley (1994). For discussions on mortgage market development
} 
following sections of this paper are organized as follows: Section 2 presents the model based on which simulation is conducted; Section 3 explains how the parameter values are chosen for the model; Section 4 discusses the simulation results; and Section 5 concludes the paper.

\section{THE MODEL}

The paper uses a six-period overlapping generations model based on that of Hayashi, Ito, and Slemrod (1988) and Slemrod (1982). ${ }^{3}$ It is assumed that each household lives for six periods, each period corresponding to a ten-year duration beginning at age 20 and stretching to age $80 .{ }^{4}$ A model with less than six periods loses the advantages of realistically modeling both the homeowner's age profiles and the mortgage maturities, while the benefits of dividing a lifetime into even more periods are not worth the accompanying computational complications.

For mathematical tractability, it is assumed that the household's lifetime utility function is additively separable with a constant discount factor. Each generation of household born in time $i$ maximizes its utility with respect to:

$$
\begin{gathered}
t_{b}, t_{s},\left\{c_{i t}, t=1 \ldots 6\right\},\left\{h_{i t}, t=1 \ldots t_{b}, t_{s}+1 \ldots 6\right\}, \text { and } H_{i}, \\
\sum_{t=1}^{t_{b}} \beta^{t-1}\left\{\log c_{i t}+\theta \log h_{i t}\right\}+\sum_{t=t_{b}+1}^{t_{s}} \beta^{t-1}\left\{\log c_{i t}+\theta \log \gamma(1-\delta)^{t-t_{b}} H_{i}\right\}+\sum_{t=t_{s}+1}^{6} \beta^{t-1}\left\{\log c_{i t}+\theta \log h_{i t}\right\}
\end{gathered}
$$

subject to:

$$
\begin{aligned}
& a_{i 0}=0, \\
& a_{i t}=\left(1+r_{t}(1-\tau)\right) a_{i t-1}+w_{t} l_{i t}-c_{i t}-R_{t}(1-\tau) p h_{i t} \quad t=1 \ldots t_{b}-1 \\
& a_{i t}=\left(1+r_{t}(1-\tau)\right) a_{i t-1}+w_{t} l_{i t}-c_{i t}-R_{t}(1-\tau) p h_{i t}-d p H_{i}, \quad t=t_{b} \\
& a_{i t}=\left(1+r_{t}(1-\tau)\right) a_{i t-1}+w_{t} l_{i t}-c_{i t}-v_{m}(1-d) p H_{i}, \quad t=t_{b}+1 . . t_{s}-1
\end{aligned}
$$

strategies, see Buckley and Gross (1985), Lomax (1994), Lea and Renaud (1995), Renaud (1996), Anderson and Kauko (1996), and Datta and Jones (1999).

\footnotetext{
${ }^{3}$ The model is also very similar to that of Ranney (1981), which uses a continuous instead of a discrete setup and the timing of purchase is exogenous. Another similar model was used by Artle and Varaiya (1978), where the timing of a purchase is endogenous but the size of a house to buy is exogenous.
}

\footnotetext{
${ }^{4}$ We assume that agents younger than age 20 follow their parents and do not make their own economic decisions.
} 


$$
\begin{aligned}
& a_{i t}=\left(1+r_{i}(1-\tau)\right) a_{i t-1}+w_{t} l_{i t}-c_{i t}-v_{m}(1-d) p H_{i}+p(1-\delta)^{t_{s}-t_{b}} H_{i}, \quad t=t_{s} \\
& a_{i t}=\left(1+r_{t}(1-\tau)\right) a_{i t-1}+w_{t} l_{i t}-c_{i t}-R_{t}(1-\tau) p h_{i t} \quad t=t_{s}+1 \ldots 6 \\
& a_{i t}=0 \\
& a_{i t}+d p H_{i}+\sum_{m=1}^{t-t_{b}}\left[v-\left(v-v_{m}\right) / \tau-\delta(1-\delta)^{t-t_{b}-1}\right] p H_{i} \geq 0, \quad t=1 \ldots 5
\end{aligned}
$$

where in the utility function, $\beta$ is the intertemporal discount factor, which is constant for all generations in all periods. $c_{i t}$ is the amount of nonhousing consumption that generation $i$ chooses for period $t . \theta$ represents the ratio of expenditure that goes to housing consumption relative to nonhousing consumption per period. $h_{i t}$ is the amount of rental housing services that generation $i$ chooses for period $t . H_{i}$ is the amount of owned housing consumption that generation $i$ chooses, which remains constant for that generation once a house is purchased. $\gamma$ is the pride of ownership, which can be explained as, for example, the advantage of eliminating the principal-agent relationship if one rents from oneself, i.e., a renter cannot alter and improve a house as desired and a renter is subject to a risk of rental increase or termination of lease. $\delta$ is the depreciation rate of a purchased house. $t_{b}$ is the time period for buying a house, and $t_{s}$ is the time period for selling a house.

In the constraints, $a_{i t}$ is the end-of-the-period financial asset value (exclusive of housing equity), which is a residual of the consumer's choices. $r_{t}$ is the interest rate on financial assets and liabilities in time $t$, which will be determined by the general equilibrium. $R_{t}$ is the relative price of rental housing. In equilibrium, $R_{t}$ must be such that the after-tax return to holding rental housing as an asset will be the same as holding industrial (nonhousing) capital as an asset. That is, the following condition must hold:

$$
\sum_{t=0}^{\infty} \frac{R_{t}(1-\tau)(1-\delta)^{t}}{\prod_{j=1}^{t}\left(1+r_{j}(1-\tau)\right)}=1
$$

$p$ is the price per unit of owned housing. The fact that $p$ is a constant implies that $H_{i}$ represents not only the size but also the quality of housing, which is also why $H_{i}$ is infinitely divisible. $d$ is the required down payment ratio, which is the required fraction of selffinancing in the total value of the housing purchase. $m$ is associated with the mortgage maturity and represents the repayment time periods, for example, $\mathrm{v}_{\mathrm{m}}$, is the mortgage repayment at period $m$. Finally, $\tau$ is the tax rate on income from financial assets. For simplicity, no bequest is assumed in the model, which is embodied by the no-bequest conditions in Equations 1 and 7. Equations 2 to 6 are the budget constraints over a lifetime. Finally, Equation 8 represents the liquidity constraint - it is assumed that no borrowing is allowed for nonhousing consumption, therefore, assets inclusive of housing must be nonnegative. In addition, an amount of down payment must be made before a household can borrow for housing purchase. In Section 3, the legitimacy of using the down payment ratio as 
a proxy for the liquidity constraint will be discussed. As a result, the two terms of down payment ratio and liquidity constraint (or equivalently, borrowing constraints or mortgage availability conditions) will be used interchangeably in future discussions.

Technology in the economy is summarized by the following aggregate production function:

$$
Y_{t}=A_{t} K_{t}^{\alpha} L_{t}^{1-\alpha}
$$

where $Y_{t}$ is the aggregate output, $K_{t}$ is the aggregate capital stock, and $L_{t}$ the aggregate labor supply. It is assumed that $L_{t}=L_{0}(1+\mathrm{n})^{\mathrm{t}}$ where $n$ is the population growth rate and $L_{0}$ is normalized to be one. Depending on how the technological parameter $A_{t}$ is specified, one can obtain as special cases the Solow exogenous growth model or the Romer endogenous growth model. This paper considers only the Romer endogenous growth model. That is, $A_{t}=A \overline{K_{t}^{\eta}}$ where $\overline{K_{t}}$ is the aggregate level of capital. In other words, the state of technology evolves as a function of the capital level. A standard postulation for this form of technology evolution is that at the level of the firm, technology displays constant returns to scale; but that at the aggregate level, technology obeys increasing returns to scale owing to externalities or spillovers. As a result,

$$
Y_{t}=A \overline{K_{t}^{\eta}} K_{t}^{\alpha} L_{t}^{1-\alpha}
$$

It is assumed that the economy comprises many small competitive forms, each of which is using the same technology in production. On one hand, firms ignore the externality and maximize profits without considering the aggregate capital level $\overline{K_{t}}$; on the other hand, in equilibrium, $\overline{K_{t}}=K_{t}$. As a result, following Romer's recommendation to set $\alpha+\eta=1$, the equilibrium output production and factor prices are:

$$
\begin{aligned}
& Y_{t}=A K_{t} L_{t}^{1-\alpha} \\
& w_{t}=(1-\alpha) A K_{t} L_{t}^{-\alpha}, \text { and } \\
& r_{t}=\alpha A L_{t}^{1-\alpha} .
\end{aligned}
$$

Note that as always, $w_{t} L_{t}+r_{t} K_{t}=Y_{t}$. The production function features increasing returns to scale in total factor, but constant returns to scale in capital.

It is assumed that industrial capital depreciates completely each period. Thus in equilibrium, all aggregate savings go to capital accumulation. That is, $S_{t}\left(r_{t}\right)=K_{t+l}$, where aggregate savings is the sum of periodic savings of all six generations at certain point of time.

To summarize, the household chooses for each of its six living periods the consumption levels of both a nonhousing composite commodity and housing commodity that are generated either by purchasing or by renting. For the housing commodity, the household can choose 
either to rent housing for its entire life or to buy and sell a house at any period of its life. The household cannot borrow to finance nonhousing consumption. It can, however, borrow toward purchasing a house, provided it can afford a down payment which is some percentage of the value of the house. The household makes all these decisions by maximizing the discounted sum of lifetime utilities subject to the lifetime budget constraints, the liquidity constraints, and the technology conditions. By comparing the maximized values of lifetime utilities for different patterns of tenure choice, the household picks the tenure pattern that yields the highest utility.

\section{Parameterization of The Model}

Because it is too complex to analytically pin down a closed-form solution for a six-period overlapping generations model with endogenous growth, a simulation method is adopted in the paper. The simulation is calibrated on the Middle East on the following two accounts: first, population growth and the urbanization process are both fast in this region, thereby imposing a great challenge to the housing sector. In fact, the population of this region has been growing more rapidly in the past three decades than any other region in the world except for sub-Saharan Africa, and its forecasted growth for the next 15 years doubles the world average. ${ }^{5}$ The urban population growth is even faster. ${ }^{6}$ On the other hand, the housing supply does not match the population growth. Although the homeownership rates are not extremely low in this region by international standards, the housing conditions-in terms of floor area per person and persons per room, for example—are particularly poor. ${ }^{7}$ To satisfy the unmet demand for good quality housing, numerous methods can be applied, one of which is to improve the housing finance system. This paper focuses on one channel of the housing finance system - the mortgage market. Instead of discussing the effects of the mortgage market development on housing demand and supply, however, this paper raises and answers the question pertaining to the effects of the mortgage market development on aggregate savings and economic growth.

\footnotetext{
${ }^{s}$ The population growth for the world average during the period of $1970-2000$ is 1.7 percent, while the population growth of the Middle East in the same period is 2.9 percent. The projected population growth for the world average between $2000-15$ is 1.1 percent whereas the projected number for the Middle East is 2.2 percent (Dhonte and others, 2000).

${ }^{6}$ For example, in 1998, the urban population growth in Jordan was 3.6 percent, much higher than the total population growth which was 2.8 percent. Similarly in Pakistan, the urban population growth was 3.9 percent in comparison with a total population growth of 2.4 percent (World Development Indicators, 1998/99).

${ }^{7}$ For detailed numbers on homeownerships, floor area per person, and persons per room in some of the Middle East countries as well as in other countries, see Housing Indicators Program, Volume II (World Bank, 1993).
} 
Second, while mortgage financing is taken for granted in the United States, a mortgage market either does not exist or fails to serve the vast majority of homebuyers in the Middle East. For example, the outstanding mortgage loans as a percentage of GDP is 0 in Algeria, about 3 percent in Egypt, 4 percent in Morocco and Pakistan, 6 percent in Tunisia, and 10 percent in Jordan. By contrast, the outstanding mortgage loans as a percentage of GDP is about 90 percent in the United States, 58 percent in the United Kingdom, 30 percent in the European Union on average, and 25 percent in Malaysia, a developing country where the financial sector is more advanced. ${ }^{8}$ Another indicator that measures the level of market intermediation in the housing sector is the annual ratio of mortgage loans to total investment in housing. This ratio is about 0 in Algeria, 11 percent in Pakistan, 20 percent in Tunisia, 25 percent in Morocco, and 34 percent in Jordan. By comparison, the ratio is about 131 percent in the United States, 150 percent in Hong Kong, 85 percent for the OECD countries on average excluding the United States and Turkey, and 74 percent in Malaysia. ${ }^{9}$ Moreover, the small mortgage markets in the Middle Eastern countries are dominated by merely a few banks, ${ }^{10}$ which further impedes competition and thereby exacerbates the mortgage market conditions. ${ }^{11}$ This paper is to examine, in the context of scarce mortgage availability, whether the development of mortgage markets can be beneficial to growth through the channel of savings.

\footnotetext{
${ }^{8}$ The data for Jordan, the United States, and Malaysia are 1994/95 numbers from World Bank (1996). The figure for Morocco is a 1998 number from Kabbaj (1999). The number for the United Kingdom is from Lomax (1991). The number for the EU is from Dhonte and others (2000). The data for Egypt, Tunisia, Algeria, and Pakistan are 1992 numbers calculated by the author according to the data in the Housing Indicators Program (World Bank, 1993), the World Development Indicators, and the Intemational Financial Statistics. They are only rough estimates, and may also have included housing loans from the government and informal loans from employers, developers, and families and friends. The figures calculated using the same method for the other countries are consistent with those from other sources.
}

${ }^{9}$ The figures for Pakistan and the OECD average are from Buckley (1994). The numbers are from the 1980s. All the other figures are from the Housing Indicators Program, Volume II, (World Bank, 1993). The figures are from the 1992 numbers.

${ }^{10}$ In Jordan, the great majority of bank lending for housing is done by the Housing Bank and the Jordan Islamic Bank (World Bank (1996) and PADCO (1999)). In Tunisia, the Housing Bank (created in 1989) owns 75 percent of total outstanding housing loans as of 1993 (World Bank 1994). In Morocco, the Credit Immobilier et Hotelier (CIH) and Banque Centrale Populaire (BCP) hold 57 percent and 18 percent of the market, respectively, in 1998 (Kabbaj, 1999).

${ }^{11}$ One may argue that the informal credit for housing through employers, developers, and families and friends has satisfied a significant amount of demand for housing finance and consequently, there is not much need for the expansion of formal mortgage credit. First, there is no available statistics on the volume of the informal housing credit, and second, many indicative estimates suggest that the informal housing loans are small in size, short in maturity, and constitute a very small proportion of the housing finance system in the region (see World Bank (1994), World Bank (1996), and PADCO (1999)). It is not clear whether bequests in the form of housing play an important role in the region's housing finance systems. To make it clear, we need detailed information on the homeowners' age profiles or the homeownerships by age group. A similar investigation was done for Italy where homeownership is relatively high and the mortgage market is relatively small (Guiso and others, 1994). 
The values of the parameters in the model are specified as follows:

1. $\beta=0.776$, which corresponds to an annual discount rate of 0.975 , similar to that employed in other studies. ${ }^{12}$

2. $\theta=0.20$, i.e., the ratio of expenditures on housing consumption to nonhousing consumption is $0.2 .^{13}$

3. $\delta=0.1$ or 0.2 . It is assumed that for better quality houses (corresponding to a bigger $\left.\mathrm{H}_{\mathrm{i}}\right), \delta=0.1$, and for worse quality houses, $\delta=0.2$.

4. $\tau=0.15$. The income tax is usually progressive and ranges from 0 to 30 percent. Since fiscal policy is not the focus of this paper, the medium value is picked as the flat tax rate for the sake of simplicity. In addition, it is assumed that income from savings is taxable, rental income is taxable, and interest payments on mortgages are tax-exempt.

5. $\quad \gamma=1.2$. The pride of ownership is assumed to be 1.2 , which is based on the assumptions of similar studies. ${ }^{14}$

6. The lifetime labor endowments are normalized so that $\sum_{t=1}^{6} l_{0 t}=1$, where $1_{0 \mathrm{t}}$ is calculated by multiplying the average income for an age bracket by the corresponding labor participation rate. For the present model, the calculated figures are as follows: ${ }^{15}$

$$
l_{o 1}=0.995, l_{02}=0.208, l_{03}=0.323, l_{04}=0.266, l_{05}=0.108, l_{06}=0 \text {. }
$$

7. The mortgage maturity is specified to be 20 years. ${ }^{16}$ Consequently, the equal repayment per period $v$ can be calculated by:

\footnotetext{
${ }^{12}$ For example, Slemrod (1982) assumes $\beta=0.776$; Hayashi and others (1988) specifies $\beta=0.75$.

${ }^{13}$ This is roughly the figure for Jordan, 1992. See Compendium of Social Statistics and Indicators, (United Nations, 1997).

${ }^{14}$ Hayashi and others (1988) chose $\gamma=1.4$.

${ }^{15}$ The average wage incomes by age group are from Jaber, Buhbe, and Smadi (1990). The labor participation rates by age group are from the Statistical Abstract of the ESCWA Region (United Nations, 1998). Both comprise data from Jordan. Because there exists inconsistency in the timing of the available data and differences in the age group categorizations from the two data sources, the author has made certain adjustments.

${ }^{16}$ The small number of available housing loans in the region usually have terms ranging from 4-20 years. See PADCO (1999) and World Bank (1994).
} 


$$
\frac{v}{\left(1+r_{t_{b}}\right)}+\frac{v}{\left(1+r_{t_{b}}\right)^{2}}=1-d,
$$

where $\mathrm{d}$ is the required down payment ratio and $r_{t_{b}}$ is the mortgage interest rate set at the time of housing purchase. The solution is:

$$
v=\frac{(1-d)\left(1+r_{t_{b}}\right)^{2}}{\left(2+r_{t_{b}}\right)} .
$$

The real repayment in each period, however, is not $v$ due to the tax exemption on mortgage interest payment. The actual payments are as follows:

$$
\left.v_{1}=v-(1-d) r_{t_{b}} \tau \text { and } v_{2}=v-\left[(1-d) r_{t_{b}}\right)-v\right] r_{t_{b}} \tau
$$

8. $\alpha=0.35$, which implies that the labor share of output is 0.65 , as is commonly postulated in growth studies.

9. $\eta=0.65$, following the recommendation of Romer (1986) to assume that $\alpha+\eta=1$.

10. $A=2$. The initial value of technology is so assumed in order for the system to converge.

11. Down payment ratios, housing prices, and population growth rates are the parameters that will be changed in the simulation. Different scenarios formed by the different combinations of these three parameters will be investigated. In Case I, the housing price is specified to be 0.5 and the annual population growth rate is 2.2 percent. ${ }^{17}$ In Case II, the housing price is maintained but the population growth rate is increased to 3.6 percent.

Finally, in Case III, the housing price is raised from 0.5 to 1 while the population growth rate is kept at 3.6 percent. For each of the three cases, the effects of changing the down payment ratios are evaluated on the steady state savings rates, real per capita output growth rates, lifetime consumption profiles, and the household's welfare levels.

In this paper, the down payment ratio is used as a proxy for mortgage credit availability, or synonymously, the liquidity constraint in mortgage markets. Potentially, there are three indices one can choose as a proxy: the down payment ratio; the spread between the mortgage

\footnotetext{
${ }^{17}$ The housing price is defined as the ratio of the median free-market price of a dwelling unit to the median annual household income, divided by 10 (in order to adjust the period from annual to decade in accordance with the model). The values for Jordan, Egypt, Morocco, Tunisia, and Algeria are 0.4, 0.7, 0.7, 0.6, and 1.2, respectively. See Housing Indicator Program, Volume II (World Bank, 1993). The population growth of 2.2 percent is the projected regional average for 2000-15 (Dhonte and others, 2000). The population growth of 3.6 percent is the urban population growth rate of Jordan in 1998 World Development Indicators.
} 
borrowing rate and an appropriate long-term lending rate; and the mortgage maturity. Since the variations in mortgage maturities are usually small, the mortgage maturity is typically not used as an index. The wedge between the borrowing and lending rates has been employed as a measure of capital market imperfection and liquidity constraints in some previous studies (e.g., King, 1986). Some recent research, however, finds that the interest rate wedges do not explain the cross-country variations in the sizes of the mortgage markets (Jappelli and Pagano, 1989). On the other hand, the down payment ratio is a direct indicator of liquidity constraint in that if a household cannot provide enough cash for the down payment, it is denied the mortgage, irrespective of its future ability to repay the loan. Moreover, empirical studies have shown that there is a strong positive relationship between the down payment ratio and consumer credit as a percentage of national income (Jappelli and Pagano, 1994) and that the down payment ratio stands out among various demand and supply factors -including taxes, interest rate spreads, profiles of lifetime income, age structures, as well as preferences - as the only account for the mortgage market (Jappelli and Pagano, 1989). As a result, this paper chooses to ignore the interest rate wedge in the model, hold the mortgage maturity constant in the simulations, and pick the down payment ratio as the index of liquidity constraint.

\section{Simulation}

\section{A. Basic Simulation Results}

As discussed in the previous section, this paper conducts simulations for three different scenarios. The results are shown in the three tables and six graphs attached. ${ }^{18}$ In Case I, with a regular housing price and an average population growth, when the down payment ratios are below 0.85 , an increase in the liquidity constraint induces an improvement in the household's utility, the aggregate savings rate, and the real per capita output growth rate. Nonetheless, when the down payment ratios are so high as to be above 0.85 , the household changes its housing tenure pattern, postponing its purchase of the house from about 30 years old to about 40 years old. In essence, this delay in purchase is a way by which the household can lessen the constraint that it faces. This change, however, causes a down-jump of 2.5 percent in the aggregate savings rate and 0.5 percent in the per capita output growth rate. Although both rates start to climb again after the down-jump, they are far lower than the values before the jump.

In Case II, with a regular housing price and a higher population growth, both the aggregate savings rates and the output growth rates are much higher than in the case of a lower population (e.g., the output growth rates increase from the neighborhood of 0.9-1.3 percent to the range of 1.1 percent to 1.7 percent, and the savings rates rise from approximately

\footnotetext{
${ }^{18}$ The savings rates and the real per capita output growth rates are in general consistent with those of Jordan in reality. See World Development Indicators and World Bank 1999.
} 
12-15 percent to about 16-19 percent), which confirms the argument that a labor force expansion is an opportunity for generating higher per capita output growth ${ }^{19}$ (Dhonte and others, 2000). Further, this faster growth in output helps the household to reduce its liquidity constraints, and consequently the household does not need to put off its housing purchase even when the down payment ratios are very high. In fact, the household can even pay completely in cash without deferring the purchase.

In Case III, while the population growth is kept the same as in the previous case, the housing price is raised to a higher level. The main effect of a heightened housing price is the reduction in housing size that the household can purchase or rent. A higher housing price combined with a higher down payment ratio, however, can dramatically make lifetime rental a better choice for the household and cause the household to forsake the purchase of a house. When this happens, the household is no longer restricted by the liquidity constraints in the mortgage market and therefore its economic decisions are no longer affected by the down payment ratio. As a result, we see in the tables and graphs for Case III that when the down payment ratios are above 0.85 , the household's housing and nonhousing consumption patterns are the same for different values of the down payment ratio. By the same token, the aggregate savings rates and the output growth rates are also fixed when the down payment ratios change above 0.85 . Most important, when the household no longer needs to save for a housing purchase, the aggregate savings rates, and consequently the output growth rates, both become lower. The savings rates plummet from almost 19 percent to about 15 percent, and the real per capita output growth rates drop from approximately 1.6 percent to about 0.9 percent.

In the following subsections, the effects of the liquidity constraints on the aggregate savings and growth and on the household's welfare level will be discussed in detail.

\section{B. Savings, Growth, and Liquidity Constraints}

The first issue investigated is how much difference the liquidity constraints can make in the aggregate savings and growth rates. In all three cases, given that the tenure choice pattern is not altered, an increase of 15 percent in the down payment ratio boosts the steady state savings rate by 0.5 percent and the steady state growth rate by 0.1 percent. The positive relationship between savings, growth, and liquidity constraints is compatible with the findings of Jappelli and Pagano (1994) and Hayashi and others (1988). As explained in Hayashi and others (1988) the magnitude of the down payment ratio effect on savings and growth may not be as large as expected because if the household can choose the level of housing services that it consumes, there are two offsetting impacts from a higher down payment ratio. On one hand, higher savings is required for a given size of house; on the other hand, a higher down payment ratio induces a smaller house to be purchased.

\footnotetext{
${ }^{19}$ For simplicity, we do not distinguish here between the labor force and the population.
} 
In the simulations of this paper, however, the tenure choice patterns do change under certain circumstances. In Case I, when the liquidity constraints are too restrictive, the household postpones the timing of a purchase and in Case III, higher down payment ratios combined with a higher housing price force the household to give up ownership. In fact, this kind of effects of liquidity constraints on the tenure choice of housing is buttressed by many previous theoretical and empirical studies. For example, Brueckner (1986) uses a two-period model to illustrate the effects of the down payment constraints on housing tenure choices. It proves that for a given consumer characteristics space-with such dimensions as discount rate, lifetime income profile, and tax scheme-a rise in the down payment ratio shrinks the region in the space where home ownership is preferred to home rental. At the empirical level, Maki (1993) applies cross-sectional data of Japan and a probit model to assess the impact of liquidity constraints on the housing purchase behavior of Japanese households. The dependent variable being the probability of planning to purchase a house relative to continuing to rent a house, the coefficient of the liquidity constraint indicator is significant: an increase of $¥ 1,000$ in consumer credit can boost the probability of purchasing a house by 0.1 percent. Rosenthal and others (1991) employs cross-sectional data of the United States to test whether the credit-constrained households exhibit different elasticities of demand for housing than the less constrained households. It observes that demand elasticities differ significantly across constrained and less constrained households and that marginal changes in liquidity constraints affect housing demand. In addition, Kim (1990) states that the availability of mortgage influences both the probability that a household will own a home and how much housing a homeowner will purchase in Korea. Finally, by utilizing a large panel data set on the microeconomic information of over 400,000 households in 14 OECD countries, Chiuri and Jappelli (2000) find strong evidence that different down payment ratios affect both the probability and timing of a housing purchase.

As a result of the variation in tenure choice patterns, the relationship among savings, growth, and liquidity constraints changes accordingly. In Case I, given the new pattern of housing tenure choice, savings, growth, and liquidity constraints follow the same positive relationship (see Figures 1 and 2), but the savings and growth rates stay at a much lower level than under the alternative tenure choice pattern. In Case III, when the household abandons the goal of owning a house, the positive relationship among savings, growth, and liquidity constraints disappears because the household's decision on housing and nonhousing consumption do not depend on the down payment ratios anymore. Moreover, since the household no longer needs to save for the down payment, both the aggregate savings rates and the real per capita growth rates fall (see Figures 3 and 4).

In sum, the simulation results produce the following empirical implication: other things being equal, liquidity constraints raise long-run savings and growth to an extent that depends on the severity of the constraints, and liquidity constraints that are too stringent impede savings and growth. It is not easy, however, to test this empirical implication using cross-country data for two reasons. First of all, reliable data on net national savings, net national product; and mortgage credit availability are not available for most non-OECD countries. Jappelli and Pagano (1994) conducted two empirical studies. One is on the relationship between savings and liquidity constraints using data from 22 OECD countries, the other is on the correlation 
Figure 1. Savings and Liquidity Constraints, Case I

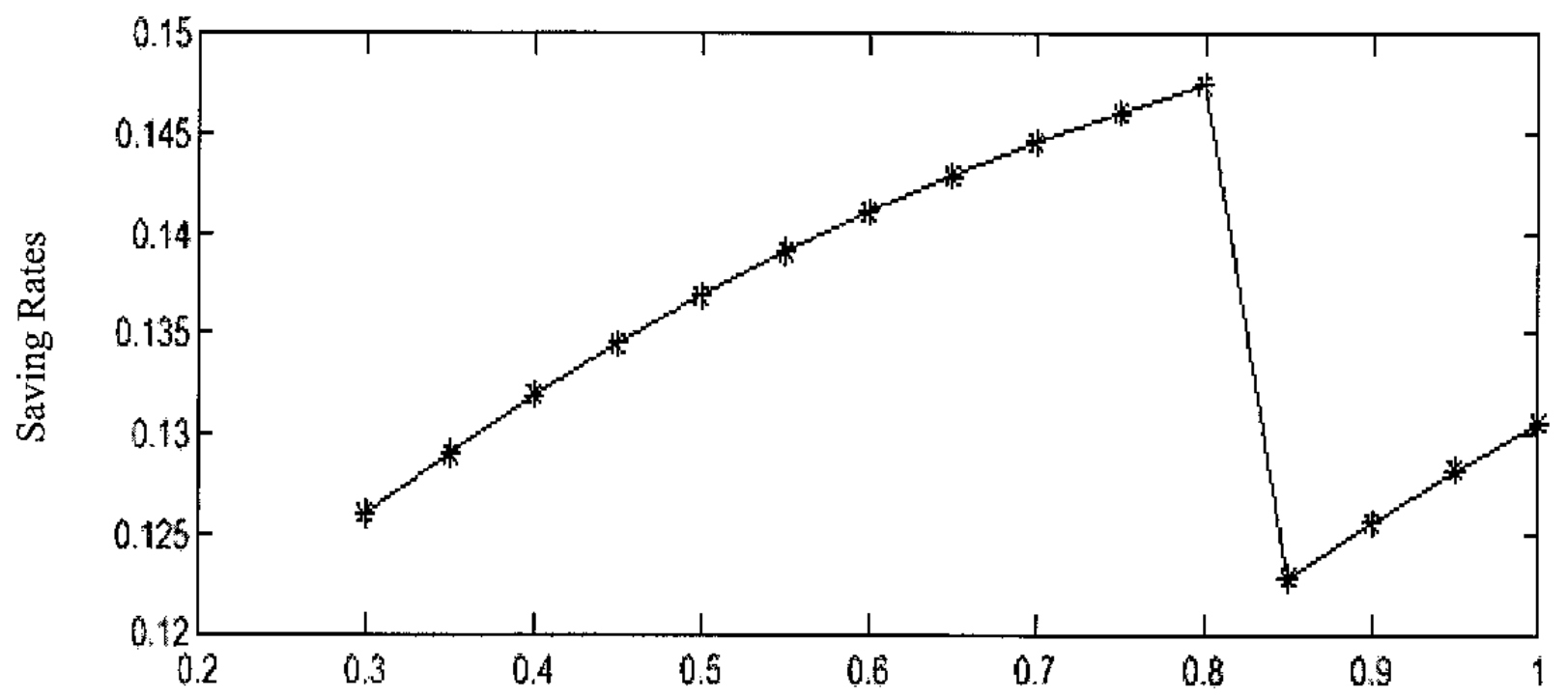

Down Payment Ratios

Figure 2. Growth and Liquidity Constraints, Case I

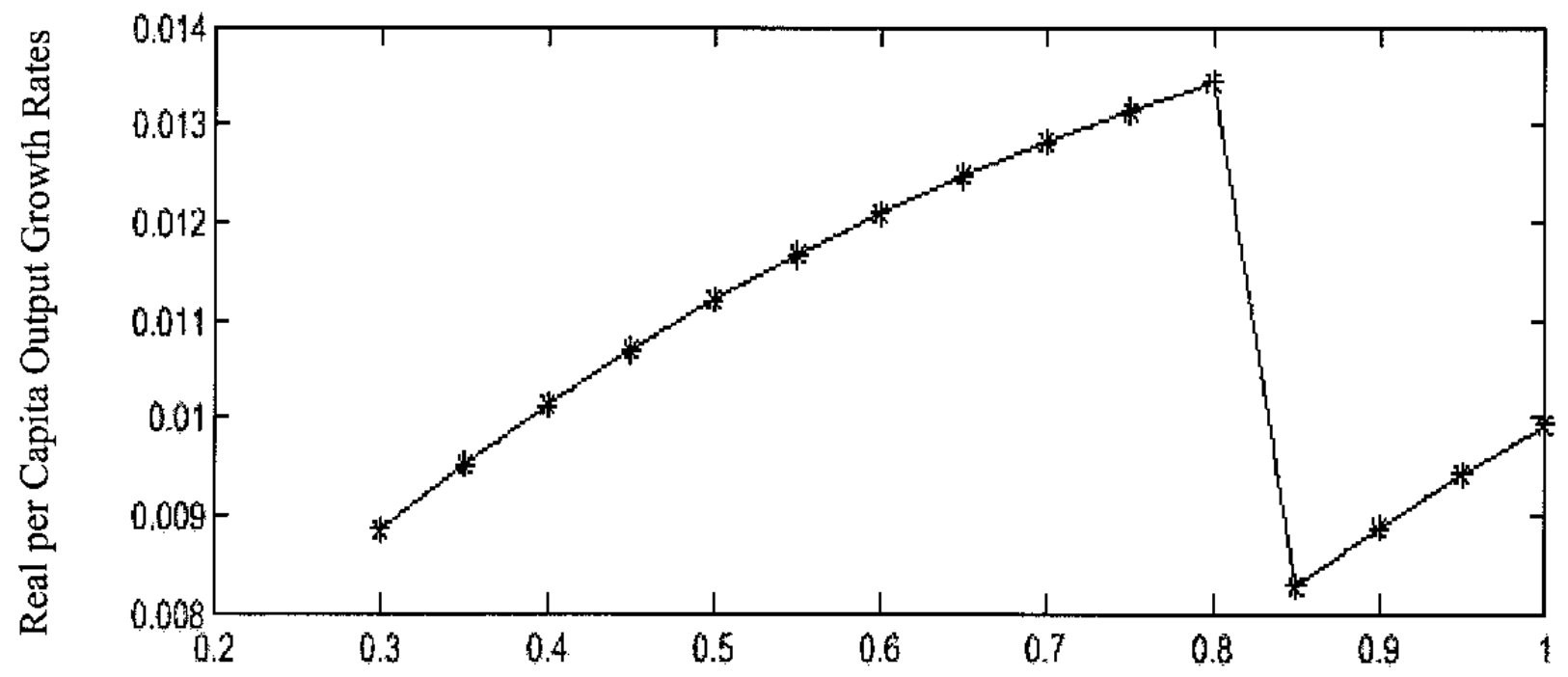

Down Payment Ratios 
Figure 3. Savings and Liquidity Constraints, Case III

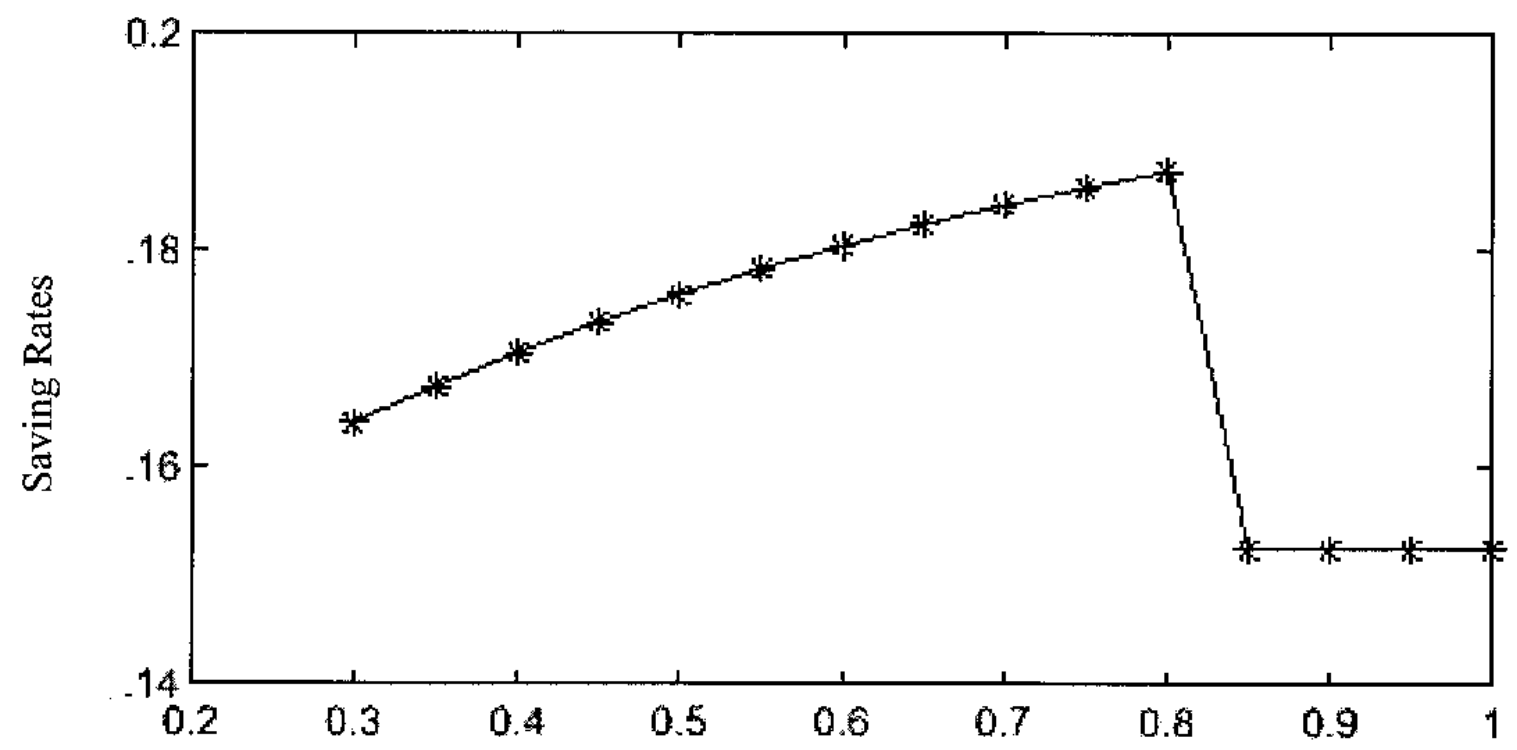

Down Payment Ratios

Figure 4. Growth and Liquidity Constraints, Case III

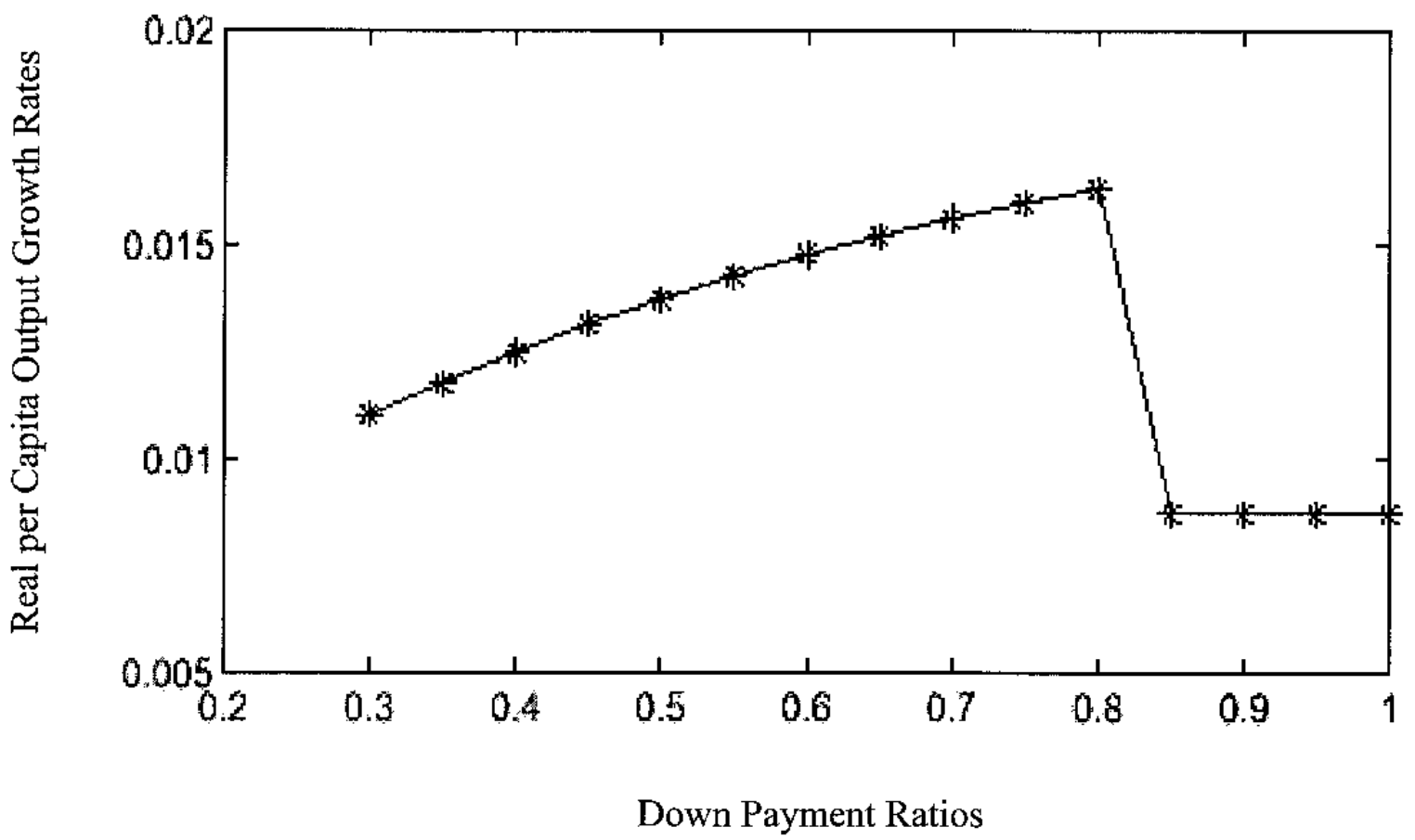


between growth and liquidity constraints using data from 30 countries-mostly the OECD plus the East Asian "tigers" before the crisis. It is not surprising that they see positive relationships in both studies since the countries they use are not facing as severe liquidity constraints as those in most developing countries. In other words, since the sample that they use in their studies is not a good representation of the population, there is sample selection bias in their estimations. If more observations from developing countries can be added to the sample, it is very likely that the results will change.

Second, conceding that data from developing countries are available, due to the fact that there is a down-jump in the savings-growth-liquidity constraint relationship, it is obvious that a simple Ordinary Least Square does not yield correct estimations. Further, because different countries' down-jump points are distinct depending on their housing price to income ratios, lifetime income profiles, tax schemes, demographic factors, etc., if one plots savings and growth against down payment ratios for all countries, one will probably see either an increased variance in savings and growth when the liquidity constraints grow higher, or the largest variance in savings and growth around a certain range of liquidity constraints. In short, some more sophisticated econometric techniques, possibly some nonparametric methods, need to be adopted to obtain correct estimates.

It is important to note that the "liquidity constraints" in this paper refer to the borrowing constraints on consumers, not on firms. Some recent studies (Bandiera and others, 2000; Loayza and others, 2000) have shown that the liquidity constraints have no significant effects on savings. Their indicators of liquidity constraints, however, do not distinguish between consumer and firm credits. For example, Bandiera and others (2000) uses the total credit to the private sector as a percentage of gross national disposable income as a proxy for liquidity constraint and Loayza and others (2000) uses an even more aggregated composite index. As pointed out in Jappelli and Pagano (1994), there is no necessary connection between the degree to which credit is available to firms and the degree to which it is available to households. Countries with abundant lending to the business sector may feature small mortgage markets and vice versa. Whether and how liquidity constraints on firms affect savings and growth is another important issue which falls outside the scope of this paper.

\section{Welfare and Liquidity Constraints}

Since binding liquidity constraints promote savings and growth, it is natural to ask if they also augment welfare. In fact, if the liquidity constraints bind, they have two opposite effects on the household's utility. On one hand, they distort the household's lifetime consumption profile by driving the consumption of the young to be lower than the unconstrained level if it wants to buy a house. This distortion implies that one should see a steeper lifetime consumption path for those who buy a house than for those who do not and for those who buy earlier than for those who buy later. This is exactly what is observed in Figure 5.

Furthermore, these observations are buttressed by the empirical findings of Zeldes (1989) and Engelhardt (1996), among others. Engelhardt (1996) applies panel data of the United States to display that households experience 10 percent higher growth in consumption across periods of home purchase than across periods without purchase. 
Figure 5. Consumption and Liquidity Constraints

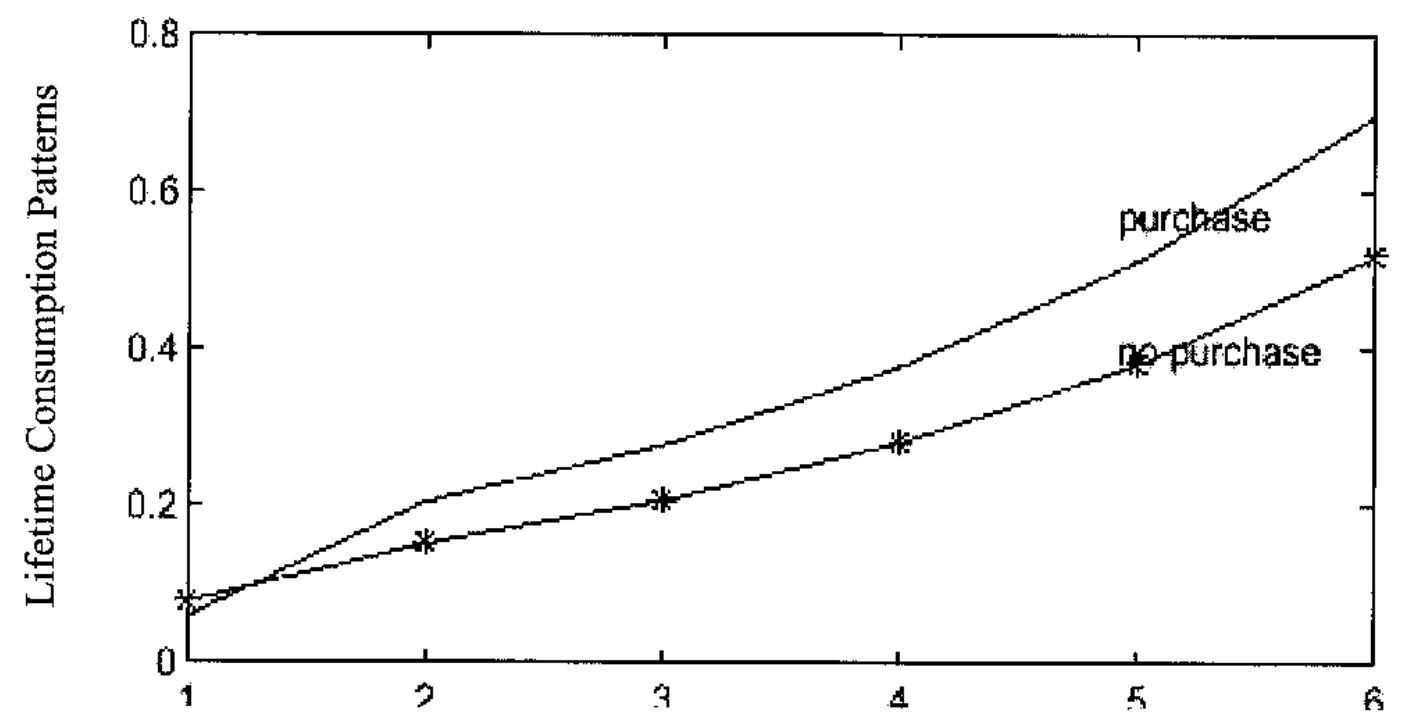

Lifetime Periods

Figure 6. Welfare and Liquidity Constraints

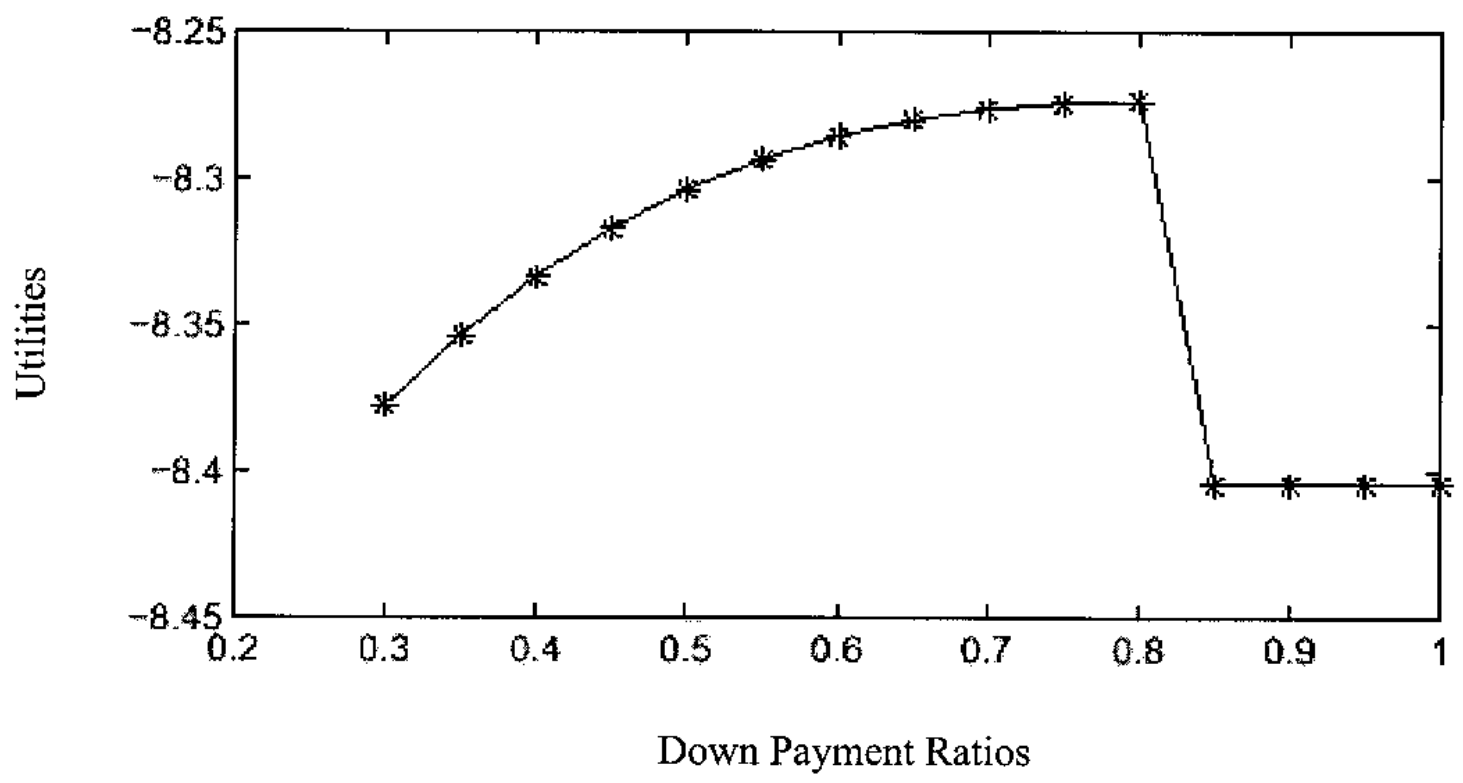


On the other hand, the liquidity constraints also raise the household's permanent income by fostering capital accumulation, and the benefit from higher capital accumulation could be large enough to outweigh the distortionary cost. The results of the simulations conducted in this paper demonstrate that in an overlapping generations model with endogenous growth, the income promotion effects may exceed the consumption distortion effects. As one can see in Figure 6, the household's utility increases with the down payment ratio when the liquidity constraint is binding. This is precisely what is predicted by Jappelli and Pagano (1999).

\section{Conclusion}

As stated in the beginning of the paper, the development of financial markets has an impact on output either through higher rate of return to capital or through more savings. Although there is little doubt that more savings induces higher output, many recent studies indicate that the effect of financial market development on savings could be negative. Instead of trying to explore the financial market development--savings relationships via a general "financial market," this paper studies only the mortgage market. It finds, by using a six-period overlapping generations model with endogenous growth and a simulation method calibrated on the Middle East, that under certain circumstances, too severe liquidity constraints in the mortgage markets can retard steady state savings and growth. This result may look contrary to the recent findings of Jappelli and Pagano (1994); it is in fact complementary. In both studies, for given tenure choices, when the liquidity constraints are binding, the higher the constraints, the higher the savings and growth rates. In the model of this paper, however, when the liquidity constraints are too restrictive, the utility-maximization household will relax its constraints by deferring the purchase of a house or by foregoing the purchase, so as to enjoy the best utility. As a consequence, when the household postpones or forsakes the purchase of a house, the aggregate savings rate and the economic growth rate fall.

Theoretically complementary as they are, this paper's results yield a completely different policy implication than that of Jappelli and Pagano (1994). Instead of suggesting tightening consumer credit to promote savings and growth, this paper's results imply that for developing countries like those in the Middle East, increasing mortgage credit availability and expanding the mortgage markets to a certain extent are conducive to savings and growth. 
Table 1. The Effects of Down Payment Ratios on Savings and Growth: Case I

House Price $=0.5$; Population Growth -2.2 percent

\begin{tabular}{|c|c|c|c|c|c|c|c|c|c|c|c|c|c|c|c|}
\hline & \multicolumn{15}{|c|}{ Down Payment Ratios } \\
\hline & 0.30 & 0.35 & 0.40 & 0.45 & 0.50 & 0.55 & 0.60 & 0.65 & 0.70 & 0.75 & 0.80 & 0.85 & 0.90 & 0.95 & 1.00 \\
\hline Utility: & -8.0261 & -8.008 & -7.9933 & -7.9818 & -7.973 & -7.9668 & -7.9627 & -7.9605 & -7.9598 & -7.9605 & -7.9622 & -7.9543 & -7.9237 & -7.8963 & -7.8718 \\
\hline Tenure: & ROOOOR & ROOOOR & ROOOOR & ROOOOR & ROOOOR & ROOOOR & ROOOOR & ROOOOR & ROOOOR & ROOOOR & ROOOOR & RROOOR & RROOOR & RROOOR & RROOOR \\
\hline$C(1):$ & 0.0685 & 0.0671 & 0.0658 & 0.0646 & 0.0635 & 0.0625 & 0.0617 & 0.0609 & 0.0602 & 0.0596 & 0.0590 & 0.0792 & 0.0792 & 0.0792 & 0.0792 \\
\hline$C(2):$ & 0.1720 & 0.1759 & 0.1795 & 0.1829 & 0.1861 & 0.1891 & 0.1918 & 0.1944 & 0.1967 & 0.1989 & 0.2009 & 0.1439 & 0.1431 & 0.1424 & 0.1417 \\
\hline$C(3):$ & 0.2253 & 0.2303 & 0.2351 & 0.2396 & 0.2438 & 0.2477 & 0.2513 & 0.2546 & 0.2577 & 0.2605 & 0.2632 & 0.2164 & 0.2213 & 0.2260 & 0.2304 \\
\hline $\mathrm{C}(4):$ & 0.2951 & 0.3017 & 0.3079 & 0.3138 & 0.3193 & 0.3244 & 0.3291 & 0.3335 & 0.3375 & 0.3413 & 0.3447 & 0.2834 & 0.2899 & 0.2960 & 0.3018 \\
\hline$C(5):$ & 0.3866 & 0.3952 & 0.4033 & 0.4110 & 0.4182 & 0.4249 & 0.4311 & 0.4368 & 0.4421 & 0.4470 & 0.4515 & 0.3712 & 0.3797 & 0.3877 & 0.3953 \\
\hline$C(6):$ & 0.5063 & 0.5176 & 0.5283 & 0.5383 & 0.5477 & 0.5565 & 0.5646 & 0.5721 & 0.5790 & 0.5854 & 0.5913 & 0.4862 & 0.4973 & 0.5078 & 0.5177 \\
\hline $\mathrm{H}$ & 0.0854 & 0.0830 & 0.0805 & 0.0778 & 0.0752 & 0.0725 & 0.0699 & 0.0674 & 0.0650 & 0.0627 & 0.0604 & 0.1252 & 0.1234 & 0.1213 & 0.1191 \\
\hline $\mathrm{H} / \mathrm{h}(1):$ & 0.0299 & 0.0292 & 0.0287 & 0.0282 & 0.0277 & 0.0273 & 0.0269 & 0.0266 & 0.0263 & 0.0260 & 0.0257 & 0.0345 & 0.0345 & 0.0345 & 0.0345 \\
\hline$H / h(2):$ & 0.0769 & 0.0747 & 0.0724 & 0.0700 & 0.0676 & 0.0653 & 0.0629 & 0.0607 & 0.0585 & 0.0564 & 0.0544 & 0.0628 & 0.0624 & 0.0621 & 0.0618 \\
\hline $\mathrm{H} / \mathrm{h}(3):$ & 0.0692 & 0.0672 & 0.0652 & 0.0630 & 0.0609 & 0.0587 & 0.0566 & 0.0546 & 0.0526 & 0.0508 & 0.0490 & 0.1127 & 0.1110 & 0.1092 & 0.1072 \\
\hline $\mathrm{H} / \mathrm{h}(4)$ & 0.0623 & 0.0605 & 0.0587 & 0.0567 & 0.0548 & 0.0529 & 0.0510 & 0.0491 & 0.0474 & 0.0457 & 0.0441 & 0.1014 & 0.0999 & 0.0983 & 0.0965 \\
\hline$H / h(5):$ & 0.0560 & 0.0545 & 0.0528 & 0.0511 & 0.0493 & 0.0476 & 0.0459 & 0.0442 & 0.0426 & 0.0411 & 0.0397 & 0.0913 & 0.0899 & 0.0885 & 0.0869 \\
\hline$H / h(6):$ & 0.2208 & 0.2257 & 0.2304 & 0.2348 & 0.2389 & 0.2427 & 0.2462 & 0.2495 & 0.2525 & 0.2553 & 0.2579 & 0.2120 & 0.2169 & 0.2215 & 0.2258 \\
\hline SV. RATE: & $12.6 \%$ & $12.9 \%$ & $13.2 \%$ & $13.5 \%$ & $13.7 \%$ & $13.9 \%$ & $14.1 \%$ & $14.3 \%$ & $14.5 \%$ & $14.6 \%$ & $14.8 \%$ & $12.3 \%$ & $12.6 \%$ & $12.8 \%$ & $13.1 \%$ \\
\hline GROWTH*: & $0.89 \%$ & $0.95 \%$ & $1.01 \%$ & $1.07 \%$ & $1.12 \%$ & $1.17 \%$ & $1.21 \%$ & $1.25 \%$ & $1.28 \%$ & $1.31 \%$ & $1.34 \%$ & $\mathbf{0 . 8 3} \%$ & $0.89 \%$ & $0.94 \%$ & $0.99 \%$ \\
\hline
\end{tabular}

* Growth is the real per capita annual output growth rate. 
Table 2. The Effects of Downpayment Ratios on Savings and Growth: Case II

House Price $=0.5$; Population Growth -3.6 percent

\begin{tabular}{|c|c|c|c|c|c|c|c|c|c|c|c|c|c|c|c|}
\hline & \multicolumn{15}{|c|}{ Down Payment Ratios } \\
\hline & 0.30 & 0.35 & 0.40 & 0.45 & 0.50 & 0.55 & 0.60 & 0.65 & 0.70 & 0.75 & 0.80 & 0.85 & 0.90 & 0.95 & 1.00 \\
\hline UTILITY: & -7.8942 & -7.8700 & -7.8498 & -7.8332 & -7.8199 & -7.8096 & -7.8018 & -7.7962 & -7.7926 & -7.7905 & -7.7899 & -7.7904 & -7.7919 & -7.7942 & -7.7972 \\
\hline TENURE: & ROOOOR & ROOOOR & ROOOOR & ROOOOR & ROOOOR & ROOOOR & ROOOOR & ROOOOR & ROOOOR & ROOOOR & ROOOOR & ROOOOR & ROOOOR & ROOOOR & ROOOOR \\
\hline$C(1)$ & 0.0687 & 0.0673 & 0.0660 & 0.0648 & 0.0637 & 0.0627 & 0.0619 & 0.0611 & 0.0604 & 0.0597 & 0.0591 & 0.0586 & 0.0581 & 0.0577 & 0.0573 \\
\hline$C(2):$ & 0.1730 & 0.1772 & 0.1812 & 0.1850 & 0.1885 & 0.1918 & 0.1948 & 0.1976 & 0.2002 & 0.2027 & 0.2049 & 0.2069 & 0.2089 & 0.2106 & 0.2123 \\
\hline$C(3)$ : & 0.2350 & 0.2407 & 0.2462 & 0.2513 & 0.2561 & 0.2605 & 0.2647 & 0.2685 & 0.2720 & 0.2753 & 0.2783 & 0.2812 & 0.2837 & 0.2862 & 0.2884 \\
\hline $\mathrm{C}(4)$ : & 0.3193 & 0.3271 & 0.3344 & 0.3414 & 0.3479 & 0.3539 & 0.3596 & 0.3648 & 0.3696 & 0.3740 & 0.3782 & 0.3820 & 0.3855 & 0.3888 & 0.3918 \\
\hline$C(5):$ & 0.4338 & 0.4443 & 0.4543 & 0.4638 & 0.4726 & 0.4808 & 0.4885 & 0.4956 & 0.5021 & 0.5082 & 0.5137 & 0.5189 & 0.5237 & 0.5282 & 0.5323 \\
\hline$C(6):$ & 0.5894 & 0.6037 & 0.6173 & 0.6301 & 0.6421 & 0.6532 & 0.6636 & 0.6732 & 0.6821 & 0.6904 & 0.6980 & 0.7050 & 0.7115 & 0.7176 & 0.7232 \\
\hline $\mathrm{H}$ & 0.0837 & 0.0815 & 0.0791 & 0.0767 & 0.0742 & 0.0717 & 0.0692 & 0.0668 & 0.0645 & 0.0622 & 0.0601 & 0.0580 & 0.0561 & 0.0542 & 0.0525 \\
\hline $\mathrm{H} / \mathrm{h}(\mathrm{l}):$ & 0.0275 & 0.0269 & 0.0264 & 0.0259 & 0.0255 & 0.0251 & 0.0247 & 0.0244 & 0.0241 & 0.0239 & 0.0236 & 0.0234 & 0.0232 & 0.0231 & 0.0229 \\
\hline $\mathrm{H} / \mathrm{h}(2)$ : & 0.0753 & 0.0733 & 0.0712 & 0.0690 & 0.0667 & 0.0645 & 0.0623 & 0.0601 & 0.0580 & 0.0560 & 0.0541 & 0.0522 & 0.0505 & 0.0488 & 0.0472 \\
\hline $\mathrm{H} / \mathrm{h}(3)$ & 0.0678 & 0.0660 & 0.0641 & 0.0621 & 0.0601 & 0.0580 & 0.0560 & 0.0541 & 0.0522 & 0.0504 & 0.0487 & 0.0470 & 0.0454 & 0.0439 & 0.0425 \\
\hline $\mathrm{H} / \mathrm{h}(4):$ & 0.0610 & 0.0594 & 0.0577 & 0.0559 & 0.0541 & 0.0522 & 0.0504 & 0.0487 & 0.0470 & 0.0454 & 0.0438 & 0.0423 & 0.0409 & 0.0395 & 0.0383 \\
\hline $\mathrm{H} / \mathrm{h}(5)$ & 0.0549 & 0.0534 & 0.0519 & 0.0503 & 0.0487 & 0.0470 & 0.0454 & 0.0438 & 0.0423 & 0.0408 & 0.0394 & 0.0381 & 0.0368 & 0.0356 & 0.0344 \\
\hline $\mathrm{H} / \mathrm{h}(6):$ & 0.2355 & 0.2412 & 0.2467 & 0.2518 & 0.2566 & 0.2610 & 0.2652 & 0.2690 & 0.2726 & 0.2759 & 0.2789 & 0.2817 & 0.2843 & 0.2867 & 0.2890 \\
\hline SV. RATE: & $16.4 \%$ & $16.7 \%$ & $17.1 \%$ & $17.3 \%$ & $17.6 \%$ & $17.8 \%$ & $18.0 \%$ & $18.2 \%$ & $18.4 \%$ & $18.6 \%$ & $18.7 \%$ & $18.9 \%$ & $19.0 \%$ & $19.1 \%$ & $19.2 \%$ \\
\hline GROWTH*: & $1.10 \%$ & $1.18 \%$ & $1.25 \%$ & $1.32 \%$ & $1.37 \%$ & $1.43 \%$ & $1.48 \%$ & $1.52 \%$ & $1.56 \%$ & $1.60 \%$ & $1.63 \%$ & $1.66 \%$ & $1.69 \%$ & $1.72 \%$ & $1.74 \%$ \\
\hline
\end{tabular}

* Growth is the real per capita annual output growth rate. 
Table 3. The Effects of Downpayment Ratios on Savings and Growth: Case III

House Price $=1.0$; Population Growth - 3.6 percent

\begin{tabular}{|c|c|c|c|c|c|c|c|c|c|c|c|c|c|c|c|}
\hline & \multicolumn{15}{|c|}{ Down Payment Ratios } \\
\hline & 0.30 & 0.35 & 0.40 & 0.45 & 0.50 & 0.55 & 0.60 & 0.65 & 0.70 & 0.75 & 0.80 & 0.85 & 0.90 & 0.95 & 1.00 \\
\hline UTILITY: & -8.3779 & -8.3538 & -8.3336 & -8.3170 & -8.3037 & -8.2933 & -8.2855 & -8.2800 & -8.2763 & -8.2743 & -8.2736 & -8.4042 & -8.4042 & -8.4042 & -8.4042 \\
\hline TENURE: & ROOOOR & ROOOOR & ROOOOR & ROOOOR & ROOOOR & ROOOOR & ROOOOR & ROOOOR & ROOOOR & ROOOOR & ROOOOR & RRRRRR & RRRRRR & RRRRRR & RRRRRR \\
\hline$C(1):$ & 0.0687 & 0.0673 & 0.0660 & 0.0648 & 0.0637 & 0.0627 & 0.0619 & 0.0611 & 0.0604 & 0.0597 & 0.0591 & 0.0792 & 0.0792 & 0.0792 & 0.0792 \\
\hline $\mathrm{C}(2):$ & 0.1730 & 0.1772 & 0.1812 & 0.1850 & 0.1885 & 0.1918 & 0.1948 & 0.1976 & 0.2002 & 0.2027 & 0.2049 & 0.1526 & 0.1526 & 0.1526 & 0.1526 \\
\hline$C(3):$ & 0.2350 & 0.2407 & 0.2462 & 0.2513 & 0.2561 & 0.2605 & 0.2647 & 0.2685 & 0.2720 & 0.2753 & 0.2783 & 0.2073 & 0.2073 & 0.2073 & 0.2073 \\
\hline$C(4):$ & 0.3193 & 0.3271 & 0.3344 & 0.3414 & 0.3479 & 0.3539 & 0.3596 & 0.3648 & 0.3696 & 0.3740 & 0.3782 & 0.2817 & 0.2817 & 0.2817 & 0.2817 \\
\hline$C(5):$ & 0.4338 & 0.4443 & 0.4543 & 0.4638 & 0.4726 & 0.4808 & 0.4885 & 0.4956 & 0.5021 & 0.5082 & 0.5137 & 0.3827 & 0.3827 & 0.3827 & 0.3827 \\
\hline$C(6):$ & 0.5894 & 0.6037 & 0.6173 & 0.6301 & 0.6421 & 0.6532 & 0.6636 & 0.6732 & 0.6821 & 0.6904 & 0.6980 & 0.5199 & 0.5199 & 0.5199 & 0.5199 \\
\hline $\mathrm{H}$ & 0.0418 & 0.0407 & 0.0396 & 0.0383 & 0.0371 & 0.0358 & 0.0346 & 0.0334 & 0.0322 & 0.0311 & 0.0300 & 0.0000 & 0.0000 & 0.0000 & 0.0000 \\
\hline $\mathrm{H} / \mathrm{h}(1):$ & 0.0137 & 0.0134 & 0.0132 & 0.0129 & 0.0127 & 0.0125 & 0.0124 & 0.0122 & 0.0121 & 0.0119 & 0.0118 & 0.0158 & 0.0158 & 0.0158 & 0.0158 \\
\hline $\mathrm{H} / \mathrm{h}(2):$ & 0.0376 & 0.0367 & 0.0356 & 0.0345 & 0.0334 & 0.0322 & 0.0311 & 0.0301 & 0.0290 & 0.0280 & 0.0270 & 0.0305 & 0.0305 & 0.0305 & 0.0305 \\
\hline $\mathrm{H} / \mathrm{h}(3):$ & 0.0339 & 0.0330 & 0.0320 & 0.0310 & 0.0300 & 0.0290 & 0.0280 & 0.0270 & 0.0261 & 0.0252 & 0.0243 & 0.0414 & 0.0414 & 0.0414 & 0.0414 \\
\hline $\mathrm{H} / \mathrm{h}(4)$ & 0.0305 & 0.0297 & 0.0288 & 0.0279 & 0.0270 & 0.0261 & 0.0252 & 0.0243 & 0.0235 & 0.0227 & 0.0219 & 0.0563 & 0.0563 & 0.0563 & 0.0563 \\
\hline $\mathrm{H} / \mathrm{h}(5):$ & 0.0274 & 0.0267 & 0.0260 & 0.0251 & 0.0243 & 0.0235 & 0.0227 & 0.0219 & 0.0211 & 0.0204 & 0.0197 & 0.0765 & 0.0765 & 0.0765 & 0.0765 \\
\hline $\mathrm{H} / \mathrm{h}(6):$ & 0.1178 & 0.1206 & 0.1233 & 0.1259 & 0.1283 & 0.1305 & 0.1326 & 0.1345 & 0.1363 & 0.1379 & 0.1395 & 0.1039 & 0.1039 & 0.1039 & 0.1039 \\
\hline SV. RATE: & $16.4 \%$ & $16.7 \%$ & $17.1 \%$ & $17.3 \%$ & $17.6 \%$ & $17.8 \%$ & $18.0 \%$ & $18.2 \%$ & $18.4 \%$ & $18.6 \%$ & $18.7 \%$ & $15.3 \%$ & $15.3 \%$ & $15.3 \%$ & $15.3 \%$ \\
\hline GROWTH* & $1.10 \%$ & $1.18 \%$ & $1.25 \%$ & $1.32 \%$ & $1.37 \%$ & $1.43 \%$ & $1.48 \%$ & $1.52 \%$ & $1.56 \%$ & $1.60 \%$ & $1.63 \%$ & $0.87 \%$ & $0.87 \%$ & $0.87 \%$ & $0.87 \%$ \\
\hline
\end{tabular}

* Growth is the real per capita annual output growth rate. 


\section{References}

Aiyagari, S. Rao, 1994, "Uninsured Idiosyncratic Risk and Aggregate Savings," The Quarterly Journal of Economics, (August), pp. 659-684.

Al-Khasawneh, Saleh, 1990, "Wage Distribution Among Private Sector Workers Subject to Social Security Regulations," Income Distribution in Jordan, ed. by Kamel Abu Jaber, Matthes Buhbe, and Mohammad Smadi, (Boulder: Westview Press).

Anderson, Kaare G., and Karlo Kauko, 1996, "A Cross-Country Study of Market-Based Housing Finance," Bank of Finland Discussion Papers, No. 13/96.

Arab Monetary Fund, 1999, Arab Countries: Economic Indicators, (Abu Dhabi, United Arab Emirates). , 1999, National Accounts of Arab Countries, (Abu Dhabi: United Arab Emirates).

Artle, Roland, and Pravin Varaiya, 1978, "Life Cycle Consumption and Home-ownership," Journal of Economic Theory, No. 18, pp. 38-58.

Bandiera, Oriana, and others, 2000, "Does Financial Reform Increase or Reduce Savings?" The Review of Economics and Statistics, No. 82(2) (May), pp. 239-263.

Bencivenga, Valerie R., and Bruce Smith, 1991, "Financial Intermediation and Endogenous Growth," The Review of Economic Studies, pp. 189-209.

Boleat, Mark, 1985, National Housing Finance Systems: A Comparative Study, (London: Croom Helm Ltd.).

Bonser-Neal, Catherine, and Kathryn L. Dewenter, 1999, "Does Financial Market Development Stimulate Savings? Evidence from Emerging Stock Markets," Contemporary Economic Policy, Vol. 17, No. 3 (July), pp. 370-80.

Borsch-Supan, Axel, and Konrad Stahl, 1991, "Do Savings Programs Dedicated To Homeownership Increase Personal Savings? Analysis of the West German Bausparkassensystem," Journal of Public Economics, No. 44, pp. $265-297$.

Browning, Martin, and Annamaria Lusardi, 1996, "Household Savings: Micro Theories and Micro Facts, Journal of Economic Literature, (December), pp. 1797-1855.

Brueckner, Jan K., 1986, "The Down Payment Constraint and Housing Tenure Choice," Regional Science and Urban Economics, No. 16, pp. 519-525.

Buckley, Robert M., and David J. Gross, 1985, "Selective Credit Policies and the Mortgage Market, Cross-Sectional Evidence," Journal of Money, Credit and Banking, Vol. 17, No. 3 (August).

Buckely, Robert M., 1996, Housing Finance in Developing Countries, (New York: St. Martin's Press.) 1994, "Housing Finance in Developing Countries: The Role of Credible Contracts," Economic Development and Cultural Change, pp. 317-332.

Chiquier, Loic, 1999, "Issues and Proposals for a Housing Sector Loan in Algeria," (unpublished; Washington: World Bank).

Chiuri, Maria Concetta and Tullio Jappelli, "Financial Markets Imperfections and Homeownership: An International Comparison," CSEF Working Paper No. 44, (Fisciano, Italy: The Center for Studies in Economics and Finance).

Datta, Kavita, and Gareth A. Jones, 1998, Housing and Finance in Developing Countries, (New York: Routledge Studies in Development and Society). 
Denizer, Cevdet, Holger C. Wolf, and Yvonne Ying, 2000, "Household Savings in Transition Economies," The World Bank Working Paper No. 2299, (March), (Washington: World Bank).

De Gregorio, Jose, 1992, "Liquidity Constraints, Human Capital Accumulation and Growth," International Monetary Fund, mimeo.

De Gregorio, Jose, and Pablo E. Guidotti, 1995, "Financial Development and Economic Growth," World Development, Vol. 23, No. 3, pp. 433-448.

Devereux, M.B., and G.W. Smith, 1994, "International Risk Sharing and Economic Growth," International Economic Review, No. 35, pp. 535-50.

Diamond, D.W. and P.H. Dybvig, 1983, "Bankruns, Deposit Insurance, and Liquidity," Journal of Political Economy, No. 91 (June), pp. 401-19.

Dhonte, Pierre, Rina Bhattacharya, and Tarik Yousef, 2000, "Demographic Transition in the Middle East: Implications for Growth, Employment, and Housing," IMF Working Paper 00/41 (Washington: International Monetary Fund).

Engelhardt, Gary V., 1996, "Consumption, Down Payments, and Liquidity Constraints, Journal of Money, Credit, and Banking, Vol. 28, No. 2 (May).

Greenwood, Jeremy and Boyan Jovanovic, 1990, "Financial Development, Growth, and the Distribution of Income," Journal of Political Economy, Vol. 98, No. 5, pt. 1.

Guiso, Luigi, Tullio Jappelli, and Daniele Terlizzese, 1994, "Housing Finance Arrangements, Intergenerational Transfers and Consumption: The Italian Experience," Economic Modelling, No. 11(2), pp. 145-155.

Gupta, Kanyaya L., 1984, "Financial Liberalization and Economic Growth: Some Simulation Results," Journal of Economic Development, pp. 25-43.

Hadjri, Karim, 1993, "Algerian Housing Policies, Practices and End Product," Third World Planning Review, No. 15 (3).

Hayashi, Fumio, 1985, "The Effect of Liquidity Constraints on Consumption: Across Sectional Analysis," The Quarterly Journal of Economics, No. 100 (February). , 1987, "Tests for Liquidity Constraints: A Critical Survey and Some New Observations," Advances in Econometrics, Vol. II, ed. T. Bewley, (Cambridge, New York: Cambridge University Press). , Takatoshi Ito, and Joel Slemrod, 1988, "Housing Finance Imperfections, Taxation, and Private Savings: A Comparative Simulation Analysis of The United States and Japan," Journal of the Japanese and International Economies No. 2, pp. 215-238.

Hendershott, Patric H., 1981, "The Allocation of Capital Between Residential and Nonresidential Uses: Taxes, Inflation, and Capital Market Constraints," NBER Working Paper No. 718 (July). , 1990, "The Market for Home Mortgage Credit: Recent Changes and Future Prospects," NBER Working Paper No. 3548, (December). , and Robert Van Order, 1989, "Integration of Mortgage and Capital Markets and the Accumulation of Residential Capital," NBER Working Paper No. 2847 (February).

Horioka, Charles Yuji, 1990, "Why is Japan's Household Savings Rate So High? A Literature Survey," Journal of the Japanese and International Economies, No. 4 pp. 49-92. 
, and Wako Watanabe, 1997, "Why Do People Save? A Micro-Analysis of Motives for Household Savings in Japan," The Economic Journal, No. 107 (May), pp. 537-552.

International Monetary Fund, 2000, International Financial Statistics (August), (Washington: International Monetary Fund).

Jappelli, Tullio, and Marco Pagano, 1989, "Consumption and Capital Market Imperfections:

An International Comparison," The American Economic Review, Vol. 79, No. 5 (December).

, 1994, "Savings, Growth and Liquidity Constraints," Quarterly Journal of Economics, pp. 83-109.

1999, "The Welfare Effects of Liquidity Constraints, Oxford Economic Papers, No. 51.

Jones, Lawrence D., 1997, "The Tenure Transition Decision for Elderly Homeowners," Journal of Urban Economics, No. 41, pp. 243-263.

Kabbaj, S., 1999, "Housing Sector in the Middle East," International Monetary Fund, (August) mimeo.

Kent, Richard J., 1980, "Credit Rationing and the Home Mortgage Market," Journal of Money, Credit, and Banking, Vol. 12, No. 3 (August).

, 1984, "Housing Tenure Choice: Evidence from Time Series," Journal of Urban Economics, No. 15, pp. 195-209.

King, Mervyn A., 1986, "Capital Market 'Imperfections' and the Consumption Function," Scandinavian Journal of Economics, No. 88, pp. 59-80.

Kim, Kyung-Hwan, 1990, "An Analysis of Inefficiency Due to Inadequate Mortgage

Financing: The Case of Seoul, Korea," Journal of Urban Economics, No. 28, pp. 371-390.

Lea, Michael, and Bertrand Renaud, 1995, "Contractual Savings for Housing: How

Suitable are They for Transitional Economies?" The World Bank

Policy Research Working Paper No. 1516 (Washington: World Bank).

Levine, Ross, 1997, "Financial Development and Economic Growth: Views and Agenda," Journal of Economic Literature, (June), pp. 688-726.

Levine, Ross, and Sara Zervos, 1998, "Stock Markets, Banks, and Economic Growth," The American Economic Review, (June), pp. 537-558.

Ling, David C., and Gary A. McGill, 1998, "Evidence on the Demand for Mortgage Debt by Owner-Occupants," Journal of Urban Economics, No. 44, pp. 391-414.

Liu, Liang-Yn, and Wing Thye Woo, 1994, "Savings Behavior Under Imperfect Financial Markets and the Current Account Consequences," The Economic Journal, No. 104, (May), pp. 512-527.

Loayza, Norman, Klaus Schmidt-Hebbel, and Luis Serven, 2000, "What Drives Private Savings Across the World?" The Review of Economics and Statistics, No. 82(2) (May), pp. 165-181.

Lomax, John, 1991, "Housing Finance: An International Perspective," Bank of England Quarterly Bulletin (February), pp. 56-64. 1994, "Market Structure, Institutional Development and the Provision of Housing Finance," Economic Modelling, No. 11(2), pp. 215-227.

Maki, Atsushi, 1993, "Liquidity Constraints: A Cross-Section Analysis of the Housing Purchase Behavior of Japanese Households," The Review of Economics and Statistics, pp. 429-437. 
McKinnon, Ronald I., 1973, Money and Capital in Economic Development, (Washington: The Brookings Institution).

Miles, David, 1994, Housing, Financial Markets and the Wider Economy, (New York: John Wiley \& Sons).

PADCO, 1999, Report on Alternative Housing Subsidy Schemes, presented to Ministry of Planning, The Hashemite Kingdom of Jordan (July).

Pagano, Marco, 1993, "Financial Markets and Growth," European Economic Review, No. 37 pp. 613-622.

Pozdena, Randall J., 1988, The Modern Economics of Housing: A Guide to Theory and Policy for Finance and Real Estate Professionals, (New York: Quorum Books).

Ranney, Susan I., 1981, “The Future Price of Houses, Mortgage Market Conditions, and The Returns to Homeownership," The American Economic Review, Vol. 71, Issue 3 (June), pp. 323-333.

Renaud, Bertrand, 1996, "Strategies to Develop Mortgage Markets in Liberalization Economies," Globalization and Housing Industry, ed. by Hee-Soo Chung and Dong-Sung Lee, (Seoul, Korea: Nanam Publishing House).

Romer, Paul, 1986, "Increasing Returns and Long-Run Growth," Journal of Political Economy, No. 94, pp. 1002-37.

Rosenthal, Stuart S., John V. Duca, and Stuart A. Gabriel, 1991, "Credit Rationing, and the Demand for Owner-Occupied Housing," Journal of Urban Economics, No. 30, pp. $48-63$.

Saint-Paul, G., 1992, "Technological Choice, Financial Markets, and Economic Development," European Economic Review, No. 36, pp. 763-781.

Shaw, E.S., 1973, Financial Deepening in Economic Development, (New York: Oxford University Press).

Slemrod, Joel, 1982, "Down-Payment Constraints: Tax Policy Effects in a Growing Economy with Rental and Owner-Occupied Housing," Public Finance Quarterly, Vol. 10, No. 2 (April), pp. 193-217.

Sussman, Oren, 1999, "Economic Growth with Standard Contract," European Economic Review, No. 43, pp. 1797-1818.

Suto, Isao, and John A. James, 1999, "Savings and Early Economic Growth in the United States and Japan," Japan and the World Economy, No. 11, pp. 161-183.

UNDP, 1997, A Profile of Sustainable Human Development in Lebanon, (New York: United Nations).

United Nations, 1997, Compendium of Social Statistics and Indicators (New York: United Nations). , 1998, Statistical Abstract to the ESCWA Region (New York: United Nations). 1999, Survey of Economic and Social Developments in the ESCWA Region (New York: United Nations).

World Bank, 1993, Housing: Enabling Markets to Work (Washington). , 1993, The Housing Indicators Program, Vol. I-IV (Washington: World Bank). 1994, Republic of Tunisia: Strategic Issues in Housing Finance and the Land Market (November) (Washington: World Bank). , 1996, The Hashemite Kingdom of Jordan: Housing Finance and Urban Sector Reform Project, (Washington: World Bank). 
,1999, Report and Recommendation of the President of the IBRD on a Proposed Loan to the Hashemite Kingdom of Jordan for a Third Economic Reform and Development Loan, Report No. P7306-J0, (Washington: World Bank). , 1999, Algeria: Housing Sector Development Strategy, (unpublished; Washington: World Bank),(June). , 1999, World Development Indicators, (Washington: World Bank).

Zeldes, Stephen P., 1989, "Consumption and Liquidity Constraints: An Empirical Investigation,” Journal of Political Economy, Vol. 97, No. 21, pp. 305-346. 